\title{
A Rubric to Enrich Student Writing and Understanding
}

\author{
http://dx.doi.org/10.3991/ijep.v5i2.4587 \\ T. L. Larkin \\ American University, Washington, DC USA
}

\begin{abstract}
The importance of effective communication, both written and oral, has been widely documented within the STEM community. In fact, the ability to communicate effectively is a skillset that is often required by employers. Oftentimes it is challenging to make the transition from academia to the work place. The ability to communicate well is a critical element of this transition. This paper will describe a more authentic experience using a professional conference format that provides students an opportunity to sharpen both their written and oral communication skills. The professional conference paper activity has been utilized in a second-level physics course at American University for $\mathbf{1 5}$ years. The conference paper activity allows students to experience all aspects of a professional conference, which is something that they do not get in other courses. This paper will describe the conference paper activity and focus on the use of a rubric that has recently been implemented in order to assist students during multiple phases of the writing process. Through the conference paper, students must communicate about a technical topic in physics while simultaneously connecting that topic to their major field of study. Numerous steps are involved in the paper writing process and each one is designed to emulate an actual conference. The conference paper activity and the associated rubric discussed in this paper offer a unique opportunity for multiple points of feedback, both from the instructor and from their classmates, while the writing process is taking place. Too often in academia a writing activity is designed in such a way that students merely submit their final written papers for a grade. Once a final paper is submitted, there is no opportunity for feedback that will aid in the actual development and writing of the paper. A more traditional paper writing experience does not provide opportunities for formative feedback prior to submission of the final paper. Hence, students do not have the necessary opportunities to really think about and reflect on what they are writing. This paper will address the importance of providing this more formative feedback using a unique rubric designed to assist students while the writing is actually taking place. A summary of students' perceptions of this process will also be provided.
\end{abstract}

Index Terms-Authentic assessment, formative assessment, learning outcomes, rubric development, student writing, written and oral communication.

\section{INTRODUCTION}

One focus of the current paper is to highlight the assessment strategies developed for the conference paper activity. A second focus is to detail a new assessment rubric developed as a formative assessment tool that was used to provide students with feedback as they were writing their research papers. An example of this rubric will be shared. A primary goal of the use of this rubric was to provide students with formative feedback and to provide them an additional opportunity to correct shaky logic and flawed understanding while they are working on their research papers. Opportunities to improve learning such as those provided with the formative assessment rubric are essentially absent when assessment is only done using a traditional pencil and paper exam. Furthermore, the development of strong written and oral communication skills is of critical importance when pursuing a career in a STEMrelated field. The strategies to be outlined in this paper provide a robust way of improving student communication skills while simultaneously allowing multiple opportunities to assess student learning. Before discussing these strategies, some fundamental questions will be addressed.

How can student learning be effectively measured and assessed? What is it that a traditional classroom exam really assesses? Does a student's score on an exam really provide the instructor with a definitive measure of what they have learned and understood? Moreover, can a comprehensive final exam score serve as a summative measure of what students have learned in a course? What can we learn from traditional assessment measures? Do traditional assessment measures really provide us with a robust picture of what students are learning throughout all facets of the learning process? If traditional assessment measures such as the comprehensive final exam don't provide us with an accurate and definitive measure of student learning, what does? Might an alternative assessment measure that involves a substantial writing component actually provide a notable, if not superior measure of what students have learned? Questions such as these provide the motivation for this paper. Any attempt to answer these questions might best be framed by first posing the broader question, what constitutes student learning?

\section{STUDENT LEARNING}

Certainly many definitions exist for student learning. In a broad sense learning might be considered to be a net gain in understanding, experience, skill and/or expertise pertaining to a particular knowledge set. The new Oxford American dictionary defines learning as "the acquisition of knowledge or skills through experience, practice, or study, or by being taught" [1]. Adapting their definition from Mayer [2], Ambrose, et al. describe learning as a process that leads to change [3]. In addition, these researchers suggest that the process of learning takes place in the mind of the learner and as a result, we can only infer that it has occurred based on the end products or performances of the students. Learning also involves a change in one's knowledge, beliefs, behaviors, or attitudes. This change is an evolving entity and unfolds over time. As such, change is not transient but rather has a long-term 
lasting impact on students' thoughts and actions. Ambrose, et al. argues that learning occurs as a result of experience which, in turn, increases the possibility for improved performance and future learning. The active process of learning is not something we "do" to students. Rather, learning is something students do themselves, sparked by a good teacher's efforts to provide robust opportunities.

Learning can be thought of as the direct result of how students interpret, react, and respond to their own experiences, be they conscious or unconscious, both past and present. In essence, learning is a process that is a deeply tied to an individual's world view. A world view might simply be thought of as a knowledge fingerprint, and is a permanent part of the process of knowledge acquisition. An essential piece of the teaching and learning process is the assessment of student learning. It is through the assessment of student learning that teachers and institutions of higher learning can demonstrate that their students have the necessary knowledge, skills, and core proficiencies consistent with both course and institutional goals. The different elements that contribute to the learning process can be very diverse. Learning can take place in a traditional classroom or laboratory. Fundamentally, learning can occur at any place in space or time where an individual learner happens to be at.

As teachers, we cannot simply rely on our own knowledge of a subject and our ability to articulate that knowledge to our students. An excellent attempt at content delivery by a teacher may not directly translate into excellent learning by a student. Many of us have been taught to know our subject; and, to have something to say. Connolly argues that neither of these precepts speaks to the "... messy process of learning nor to the even murkier process of thinking through written language" [4]. The art of measuring and assessing this learning continues to be one of the challenges that educators everywhere face. Effective teaching and learning imply much more than efficient transmission of information from the expert (teacher) to the novice (student) and then back again. The use of writing to enhance and assess student learning within the science classroom has a strong history [5-10]. As a learning tool, writing activities have been used in various forms as tools for alternative assessment of student understanding.

\section{THEORETICAL FRAMEWORK: WRITING AS A LEARNING TOOL}

Studies on teaching pedagogies have clearly demonstrated that traditional techniques often put students in a role of passive rather than active learning [11 - 15]. Likewise, more traditional methods have been shown to be very inadequate in terms of promoting deep learning and long-term retention of important concepts [16 - 19]. Students in traditional classrooms often acquire most of their knowledge through passive classroom lectures, textbook reading, and the internet. Passive learning routinely results in students merely trying to learn and regurgitate what the teacher and textbook are telling them. A discouraging fact is, after instruction, students often emerge from our classes with serious misconceptions [20 - 26]. Writing can be used to effectively help students confront their misconceptions. In addition, formal writing strategies can provide essential "snapshots" to help uncover what students are truly learning as the learning is taking place.
Traditional examinations and quizzes merely provide an assessment marker after a segment of material has been covered in class. While important as a point for charting progress, these forms of assessment do little to uncover what is actually taking place in the mind of the learner. Astin [27] argues that as professors, we may think that we've given a very stimulating and thought-provoking lecture, without ever really knowing how much of it was actually understood by the students, how much was retained, or whatever other kinds of effects it may have had on the students. While traditional examinations and quizzes may provide us with some information about what students are learning, this more summative type of feedback really comes a little too late. A carefully crafted writing activity or set of activities can provide a more formative and authentic assessment of student learning; and, give students and professors time to correct any misconceptions or flaws in reasoning as the learning is ongoing. The particular writing-based assessment activity to be showcased in this paper was developed for use in a second-level physics course for non-majors. Before discussing the writing activity, some details about the course setting will be presented.

\section{COURSE FORMAT}

A second-level physics course for non-majors entitled Physics for a New Millennium (PNM) at American University (AU) serves as the setting for this paper. Numerous projects and studies within the domain of Physics Education Research (PER) have pointed to the importance and value of using a learner-centered, activity-based environment. A significant outcome of these and other PER studies is; in comparison to more traditional instructional strategies, student conceptual understanding and problemsolving ability is enhanced within an activity-based learning environment [28 - 35]. The PNM course is centered around a modified workshop/studio format in which students perform a number of collaborative activities referred to in class as "collabs." This modified workshop approach includes both traditional lecture as well as numerous interactive learning experiences.

The PNM course consists of one 75-minute period each week where course content is delivered in an interactive lecture format. The second weekly period is 150 minutes in length. The double-block period is designed to give students a good deal of time to perform hands-on collaborative activities and experiments within a team-based environment.

All students enrolled in PNM have taken a first-level introductory physics course with a laboratory component. The curriculum for the second-level PNM course includes the following topic areas which are quite typical in a second-level course: sound and waves, electricity and magnetism (E \& M), light and color, optics, and (time permitting) introductory modern physics. Designed by the author, this course is taught in an interactive workshop/studio format. Throughout all aspects of the course students are given the opportunity to learn physics through both more traditional lecture as well as a number of interactive learning activities that have been developed for team-based work. During most class sessions, students have numerous opportunities to roll up their sleeves and take an active role in investigating a particular topic. Figure 1 illustrates a typical class session. In this particular figure, students are working in teams to explore the con- 
cept of electrostatics using a hands-on approach. Through this activity students learned such things as the various methods of electrostatically charging an object, the law of charges, and the law of conservation of charge. Students also learned about conduction and induction and electrical shielding through their explorations.

Collaborative activities such as the electrostatics activity have been designed for each of the major topic areas of the course. These collaborative activities are all done using a team approach. For each new activity performed new team structures are incorporated. In that way, students have an opportunity to work with every member of the class before the end of the semester. In addition, a good deal of emphasis is placed on building community throughout the semester. By the end of the term, the synergy that exists between team members is truly remarkable. In Figure 2, teams of students are working collaboratively on an investigation involving sound waves.

Figure 3 shows a team of students working on an activity to help them understand how colors are created on the viewing screen of a computer monitor. Because of the unique nature of the course, class size is limited to 16 students. The spring 2014 class consisted of 11 students.

PNM is a course that many students take to satisfy the university's general education requirements towards graduation. Approximately half of the students enrolled are also typically pursuing a minor in applied physics. A unique element of the PNM course is its active learning format along with its focus on student writing as an alternative method of assessment. This form of assessment is in contrast to more conventional classroom measures and to numerous research-based normalized tests and surveys such as the Force Concept Inventory (FCI), the ForceMotion Concept Evaluation (FMCE) the Mechanics Baseline Test (MBT), and others [36-40].

The non-traditional design and structure of the PNM course lends itself well to the development and use of alternative and perhaps more authentic assessment measures. To this end, a formal research paper is used in place of a final exam to help assess student learning throughout all aspects of the paper-writing process.

\section{CONFERENCE PAPER AND ASSOCIATED ASSESSMENT STRATEGIES}

A written conference paper serves as a direct measure for assessing student learning in the PNM course. The semester-long conference paper and the activities associated with it accounts for approximately $34 \%$ of a student's grade in the course. In addition to the conference paper activity, other more traditional assessment measures were also utilized including homework assignments, quizzes, and exams. Students also earned points through the collaborative team activities. How these points were earned varied from activity to activity. Some of the activities also had a writing component to them. For example, for the electrostatics activity discussed earlier, students were required to write down their observations throughout each step of the activity. They earned points for the quality of their written observations which made clear their understanding of the topic. This is but one example of how the collaborative activities were assessed. A complete breakdown of how the students' grades were assessed is as shown in Table I.

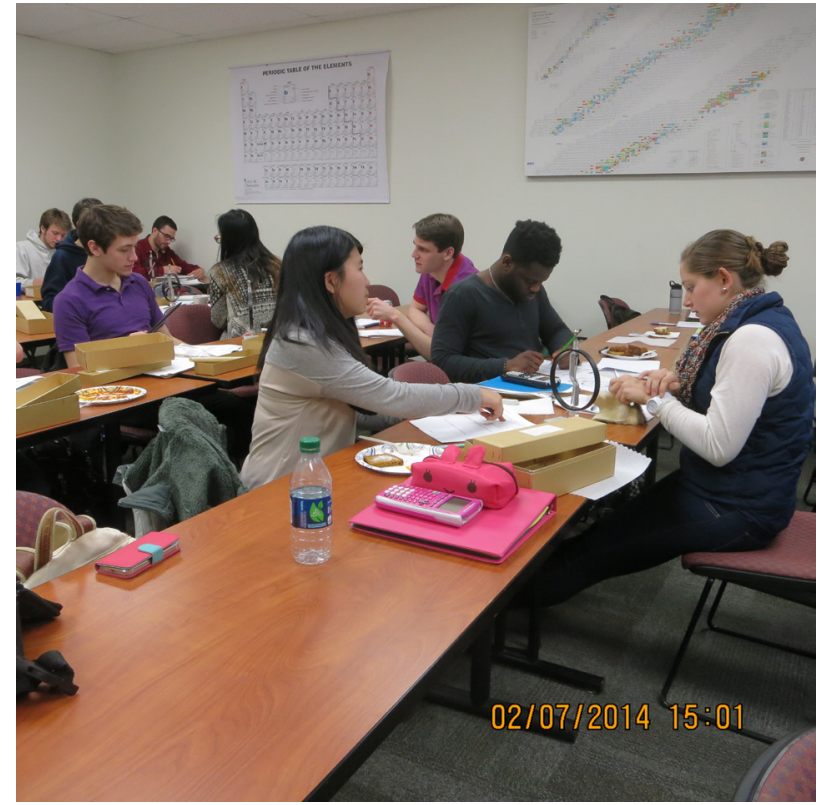

Figure 1. The workshop/studio class environment.

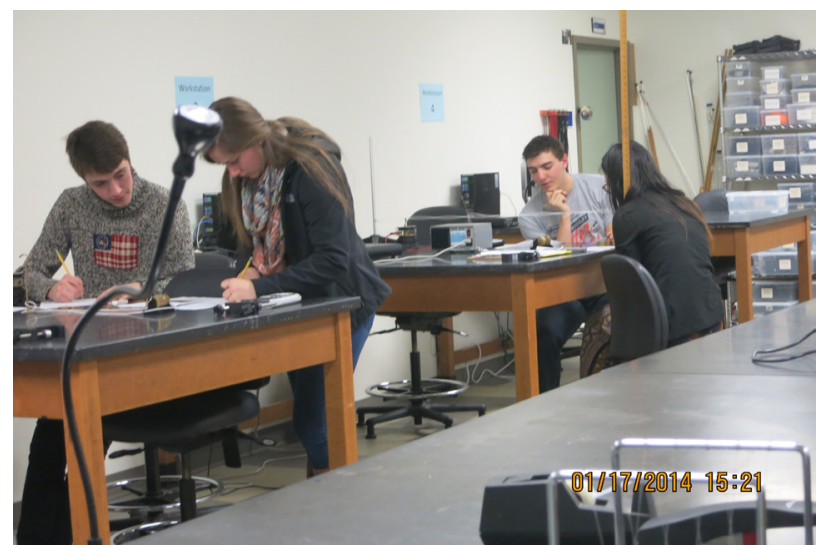

Figure 2. Teams of students performing an activity involving sound waves.

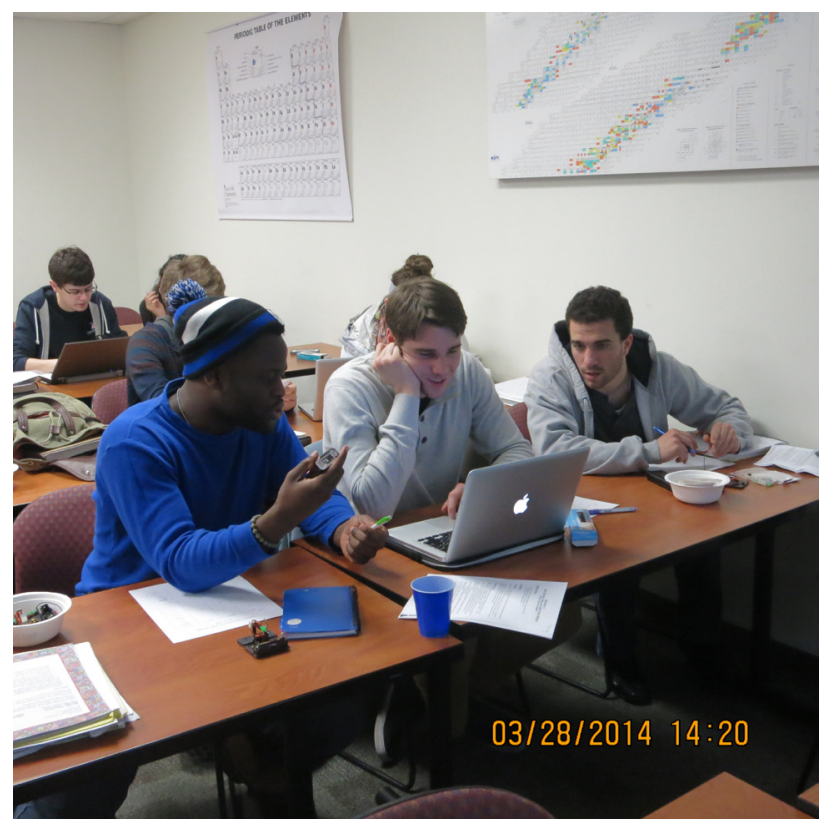

Figure 3. A team of students working on an activity involving color. 
TABLE I.

BREAKDOWN OF GRADE DISTRIBUTION

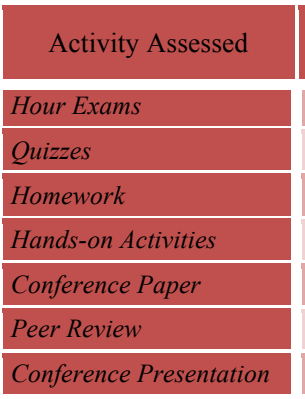

\begin{tabular}{|c|c|}
\hline Points Possible & $\begin{array}{c}\text { Percent of Total } \\
\text { Grade (\%) }\end{array}$ \\
\hline 200 & 21.1 \\
\hline 75 & 18.4 \\
\hline 175 & 18.4 \\
\hline 175 & 18.4 \\
\hline 175 & 18.4 \\
\hline 50 & 5.3 \\
\hline 100 & 10.5 \\
\hline
\end{tabular}

The conference paper activity was designed to provide students with an opportunity to experience all aspects associated with the writing and presenting of a scientific paper to an audience of their peers. Over the course of a given semester, students are exposed to all aspects of preparing a professional paper for publication. The paper writing experience includes the:

- submission of an abstract,

- preparation of a first draft for instructor review,

- preparation of a second draft for formal peer review, and

- preparation of a revised, camera-ready copy for publication in the conference proceedings.

Students are given an opportunity to select the topic for their research papers. The only requirements are that the topic chosen needs to involve one or more of the key concepts to be discussed in class. Students are further encouraged to select a topic that might have some overlap to their major field of study. For example, in the spring 2014 class a student majoring in music conducted research on the physics of the flute. Another student pursuing a major in public health with a minor in applied physics conducted research pertaining to how nuclear energy is used in a hospital setting. Yet another student who was pursuing a major in audio technology conducted their research on the physics involved with subwoofer enclosure design. These are but a few examples of the topics students choose to write about which serve to assist them in merging physics with their major areas of study.

The culmination of the students' efforts was to present their final research papers at a conference held at the end of the semester. The conference itself has come to be one of the physics department's highlights each spring. Faculty, staff, and other students are invited to attend the conference. In addition, the students' parents are sent a letter along with a conference program and an invitation to attend. Typically anywhere from $3-5$ sets of parents attend the conference event. Figures 4 and 5 show two students, Daisy and Nick respectively, presenting their research papers at the end of the semester class conference.

In her earlier work, the author described in more depth, each aspect of the paper-writing process [41]. To briefly summarize, the assessment of the conference paper is done through a variety of techniques. Each phase of the paper writing process provides the instructor with an opportunity to assess students' understanding of physics. For example, students are required to have approximately $50 \%$ of their paper focus on the physics aspects of their topics. Once a first draft is submitted the instructor provides con-

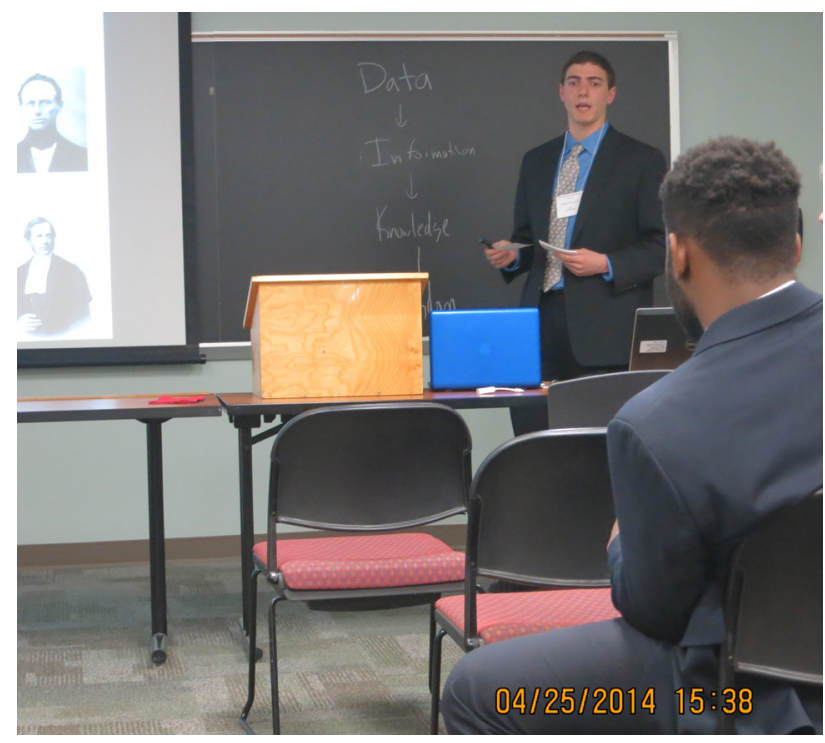

Figure 4. Daisy presenting her research during the end-of-semester class conference.

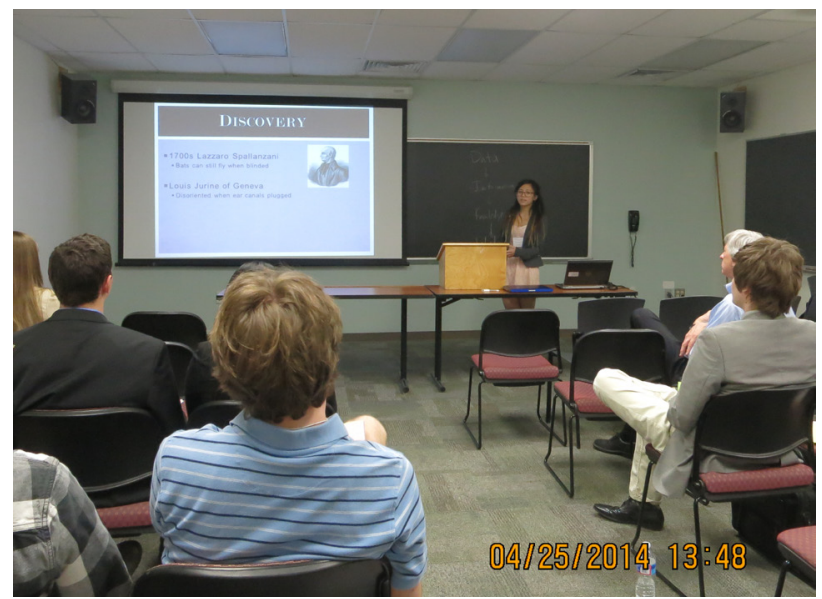

Figure 5. Nick presenting his research during the end-of-semester class conference.

siderable feedback to the students regarding the physics content of their papers. From the first to the second draft submission, students are required to meet with the instructor to discuss the physics content of their papers. Once a second draft has been submitted, students are assigned one paper for which they are to conduct a peer review. Based on the completed peer reviews, the instructor gains considerable insight into the students' understanding of physics concepts. This understanding is demonstrated through the written feedback that the students provide to their peers. Completion of the final "camera ready" copy of the paper provides additional critical documentation of how students have expanded and enriched their understanding of key physics concepts throughout the overall writing experience.

Since the conference paper takes the place of a final exam, these formative assessment points are critical to the overall assessment process. Rubrics are utilized to assess the paper as well as the peer review. Unique to the current work, a writing-based, self-reflection type of new formative assessment rubric was crafted and implemented during the spring 2014 PNM class. This assessment rubric will be discussed in the next section. 


\section{THE ASSESSMENT RUBRIC}

Requiring students to write a written research paper is not, in and of itself, unique. In most instances where a research paper is required, the only thing that is assessed is the end product. While this type of assessment might provide some insight into student learning, it is certainly lacking in many respects. Assessment of the end product provides little or no information about the actual learning process. Moreover, this type of assessment does not shed much light on how student learning was enhanced as a result of the writing experience. It is one thing to have students write a research paper in a class; and, it is quite another to assess student learning throughout the entire writing experience.

Throughout the paper writing process assessment is done at several junctures and is not based solely on the completed research paper. Each milestone of the paperwriting experience is designed to provide a snapshot which allows the instructor the opportunity to capture in real time what the students are actually learning as they are researching and writing their papers. To this end, a formal rubric is used as a record of student learning. This rubric serves as one data point to assess the overall paper. To better assess what students are learning as they are actually researching and writing their papers, a more robust and formative measure of assessment was employed during the spring 2014 semester.

One focus of the present work is to showcase the formative assessment rubric developed in part, to provide students with an additional mechanism to reflect on their work while it is ongoing. A complete and detailed copy of this rubric can be found in the appendix. In addition, through this self-reflection rubric students were often able to pinpoint flaws or gaps in their understanding about a key topic(s) in physics that they were writing about. The students in the spring 2014 PNM class were the first to have the opportunity to utilize the rubric.

The rubric described here and presented in its entirety in the appendix was crafted to parallel the key aspects students were required to include within their papers. These key aspects included:

- Abstract

- Organization

- Introduction/historical overview

- Physics synthesis

- Connection between key physics concepts and paper topic

- Summary

- Correctness

- Reference section and citations

At a point midway between the submission of the first and second drafts of the paper, each student was required to set up an appointment with the instructor. During this appointment the instructor went through each element of the rubric with the student. The goal of doing so was simple: to provide students with substantive feedback so that they could make improvements to the next draft of their papers. Students were also given the opportunity to ask any questions they had on the research they were doing. In particular, emphasis was placed on the connection between key physics concepts and their paper topics. In addition, a thorough discussion of how their papers were coming along in terms of the synthesis of key physics concepts also took place.

The use of this intermediate formative assessment rubric allowed students a non-threatening vehicle to get much needed feedback on their work. The discussion between instructor and student took on a more collegial tone. These meeting with students took approximately 15 minutes per student, with approximately 3 hours devoted to the overall task. Many students had not experienced this type of discussion with any instructor before. Students quickly understood that the purpose of the meeting was to assist them prior to submitting the next drafts of their papers. So often students tend to merely try and look for what it is that the instructor wants from them in terms of a given assignment. In this case, the instructor more or less turned the table on the students and instead asked them what they wanted the end product of their research to look like. Doing so provided an opportunity for students to really take ownership of their work.

At the conclusion of each meeting with the students, the instructor and student carefully reviewed each element of the rubric and marked it based on where the paper was currently at. There was no grade assigned for this activity. Rather, the students were given a small number of points towards their overall paper score for simply attending the meeting and putting forth a sincere effort. More importantly, this meeting helped the students to self-reflect and to make significant improvements on the next draft of their papers as evidenced by the enhancement of the physics-related portion of their individual papers. In the past, after submission of the second drafts, students' papers still tended to lack the necessary attention to this critical portion of their papers.

The students in the spring 2014 PNM class expressed a deep appreciation for the meeting with the instructor to discuss their progress in conjunction with the key elements of the rubric. During the meeting with the instructor the students were given the chance to articulate where they felt they were still having difficulties with their papers. Sometimes these difficulties were simply related to learning how to properly format their papers. Other times, the difficulties had much more to do with the actual physics content students were trying to understand, digest, and write about. Providing the students with the opportunity to discuss their difficulties proved to be a very effective mechanism to enhance the learning process for the students. Meeting to discuss their progress and how that progress related to the elements of the rubric merely opened the door for what were quite often very robust discussions. Had the rubric not been utilized the students would not have had such a formal meeting to discuss the important issues they were having with the paper. The rubric essentially provided the foundation upon which additional discussions could ensue.

Through these various discussions, students were able to self-reflect on the writing process. Through this selfreflection students were able to identify for themselves what issues remained in their minds. This is contrary to what typically happens in an academic exercise. In a typical academic exercise, the instructor asks students to complete an assignment or other activity. The students then complete the assignment or activity and submit it to the instructor for grading purposes. Often times a grade is simply issued without much feedback and the instructor then moves on to the next topic. What is missing from this 
sort of typical assignment is the chance for students to correct their understanding and oftentimes flawed thinking while they are actually completing the task. A grade on an activity post-submission does not provide this critical opportunity for feedback for the students. Hence, a critical aspect of true learning is often bypassed in more traditional assignments and activities. Once a grade has been issued, it's often too late to go back and address the specific learning issues and difficulties students might have had. Furthermore, these issues and difficulties often present themselves later on when new topics being covered demand a complete understanding of topics previously covered. Hence, the use of this formative assessment rubric helped students identify and correct flaws in their thinking and understanding BEFORE they submitted the next version of their paper. The identification of flaws in their thinking is so fundamental to the overall learning process, yet is often void in most academic exercises. Many of the students felt that this was an added "bonus" to the overall paper writing experience.

An additional bonus afforded by the formative assessment rubric is that it really served to encourage students to take ownership of their overall learning. They truly expressed a keen desire to really understand the topic they were writing about. The active process of writing helped provide them with a more authentic voice.

The overall improvement in student understanding of key physics concepts over the course of the semester was in large part due to the effort they put into this section of their research papers. Through the use of this formative assessment rubric the instructor was provided with additional information regarding the improvement of student learning that could not be uncovered through a standard classroom exam.

\section{SUMMARY}

The primary purpose of a final exam is to provide a summative marker of a student's progress in comprehending a subject over the course of a given term. At best, the final exam grade provides a single data point regarding student learning. A student's grade on a final exam does not, however, shed much light on the overall process of learning. If one is truly intent on capturing what a student has learned in a given course, other methods of assessment are required.

The spring 2014 PNM class served as a pilot for the implementation of the formative assessment rubric shared in this paper. Based on the discussions that ensued when employing this rubric, it is evident that a more real-time and robust window into the students' learning processes was able to be captured. What is perhaps the most significant is the fact that students were able to recognize and then correct any flaws in their thinking while the learning was actually taken place. A final exam simply does not permit students to do this. Instead, points are taken off and as a result an instructor is left wondering whether or not his or her students actually gained proficiency in a subject over the course of the term. The use of this assessment rubric allowed the instructor to observe students selfreflect and come to understand what was wrong with their thinking; and, more importantly why their thinking was flawed. A final exam simply does not give students this critical and vital opportunity.
One recommendation for the future would be to utilize the rubric twice during the paper writing process. As was highlighted in this paper, using the rubric between the first and second drafts of the paper was informative. Conceivably this rubric could be used a second time as students moved from the second drafts of their papers to their final drafts. In this way perhaps any remaining flaws and uncertainties students had could be even better addressed. The use of the rubric clearly had a positive impact on the students' second paper drafts. Perhaps used a second time would allow for further insight to students' thought processes. Moreover, a second implementation would provide students with an additional opportunity to ask questions and clarify their understanding about the physics content they were weaving into their papers. Finally, a second implementation would also provide yet another snapshot in time so the instructor could better and more realistically document student learning gains.

\section{ACKNOWLEDGMENT}

The author wishes to thank the many wonderful students who have taken PNM in past semesters. In particular, the author would like to acknowledge the students in the spring 2014 class (shown in Figure 6) for serving as a test-group for the use and refinement of the formative assessment rubric discussed in this paper. In addition, the author would also like to thank the spring 2014 class for permitting her the use of the photographs displayed in this paper.

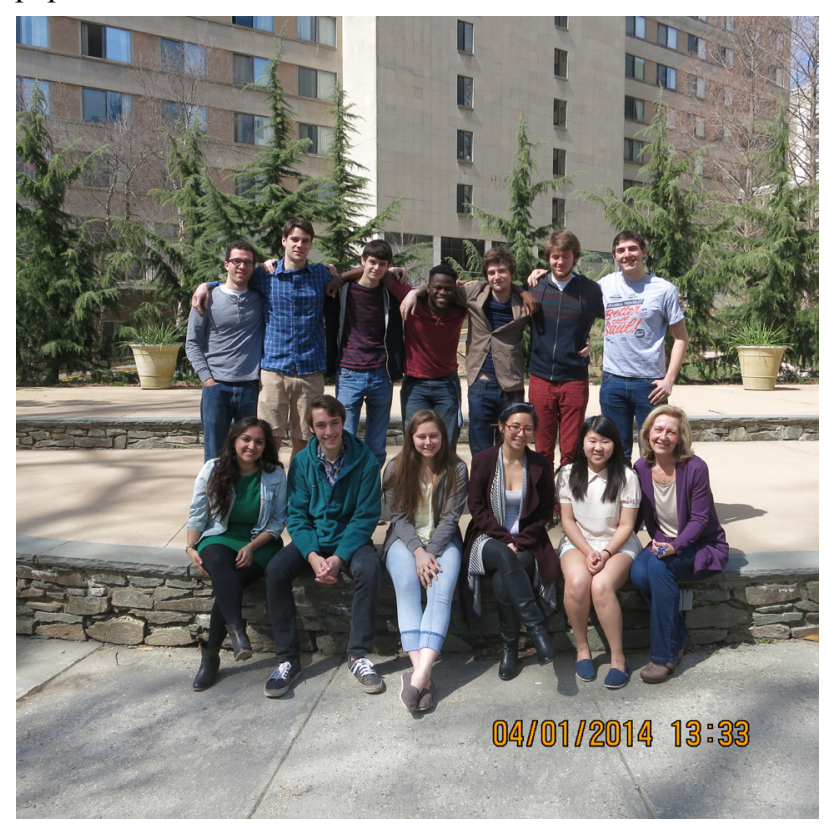

Figure 6. The spring 2014 PNM class.

\section{REFERENCES}

[1] Jewell, E. J. and Abate, F. (Eds.). (2001). The new Oxford American dictionary. New York: Oxford University Press, Inc.

[2] Mayer, R. E. (2002). The promise of educational psychology, volume 2: Teaching for meaningful learning. Upper Saddle River, NJ: Merrill Prentice Hall.

[3] Ambrose, S. A., Bridges, M. W., DiPietro, M., Lovett, M. C., Norman, M. K., (2010). How learning works: 7 research-based principles for smart teaching. San Francisco, CA: Jossey-Bass.

[4] Connolly, P. and Vilardi, T. (1989). Writing to learn mathematics and science. New York: Teachers College Press. 
[5] Hein, T. L. (1999, May). Using writing to confront student misconceptions in physics. European Journal of Physics, Vol. 20, pp. 137 - 141. http://dx.doi.org/10.1088/0143-0807/20/3/002

[6] Larkin-Hein, T. (2001, January - August). Writing as a teaching and learning tool in SMET education. Journal of SMET Education: Innovations and Research, Vol. 2, Issue 2/3, pp. 25 - 35.

[7] Kalman, C. S. (2007). Successful science and engineering teaching in colleges and universities. Bolton, MA: Anker Publishing Company, Inc.

[8] Larkin, T. L. (2012, February). Closing the loop: What do they do with our feedback? Portuguese Society for Engineering Education (SPEE) Newsletter (Sociedade Portuguesa Para A Educacao Em Engenharia), No. 5, p. 19.

[9] Larkin, T. L. (2010, June). The "write" path to effective student understanding in physics. Annual Conference of the American Society for Engineering Education, Louisville, Kentucky. electronic proceedings.

[10] Larkin-Hein, T. L. \& Joyner, P. K. (2001, January). Linking physics with college writing. Winter meeting of the American Association of Physics Teachers, San Diego, California. AAPT Announcer, Vol. 30, No. 4, p. 128.

[11] Jones, T. H. and Paolucci, R. (1998). The learning effectiveness of educational technology: A call for further research. Educational Technology Review, (9), 10 - 14.

[12] Deslauriers, L., Schelew, E., and Wieman, C. (2011). Improved learning in a large-enrollment physics class. Science, $\underline{332}, 862-$ 864. http://dx.doi.org/10.1126/science.1201783

[13] Smith, M. K., Wood, W. B., Adams, W. K., Wieman, C., Knight, J. K., Guild, N., and Su, T. T. (2009). Why peer discussion improves student performance on in-class concept questions. Science, 323,122 - 124. http://dx.doi.org/10.1126/science.1165919

[14] Mazur, E. (1997). Peer instruction: A user's manual. Upper Saddle River, N.J.: Prentice Hall.

[15] Hammer, D. (1989). Two approaches to learning physics. The Physics Teacher, 27(9), 664 - 670. http://dx.doi.org/10.1119/1.2 $\underline{342910}$

[16] Van Heuvelen, A. (1991). Learning to think like a physicist: A review of research-based instructional strategies. American Journal of Physics, $\underline{59}(10), \quad 898 \quad-\quad 907$. http://dx.doi.org/10.1119/1.166 $\underline{58}$

[17] Hestenes, D., Wells, M., and Swackhamer, G. (1992). Force concept inventory. The Physics Teacher, 30(3), 141 - 153. http://dx.doi.org/10.1119/1.2343497

[18] Maloney, D. (1994). Research on problem solving: Physics. In D. L. Gabel (Ed.), Handbook of Research on Science Teaching and Learning (pp. 327 - 354). New York: Macmillan Publishing Company.

[19] Reif, F. and Scott, L. A. (1999). Teaching scientific thinking skills: Students and computers coaching each other. American Journal of Physics, 67(9), $819 \quad-\quad 831$. http://dx.doi.org/10.1119/1.19130

[20] Arons, A. B. (1990). A guide to introductory physics teaching. New York: John Wiley \& Sons.

[21] Halloun, I. A. and Hestenes, D. (1985). The initial knowledge state of college students. American Journal of Physics, 53(11), 1043 - 1055. http://dx.doi.org/10.1119/1.14030

[22] McCloskey, M., Caramazza, A., and Green, B. (1980). Curvilinear motion in the absence of external forces: Naïve beliefs about the motion of objects. Science, 210, $1139-1141$. http://dx.doi.org/10.1126/science.210.4474.1139

[23] McDermott, L. C. (1984). Research on conceptual understanding in mechanics. Physics Today, 37, $24-32$. http://dx.doi.org/10.1063/1.2916318

[24] McDermott, L. C. (1991). A view from physics. In M. Gardner, J. Greeno, F. Reif, A. H. Schoenfeld, A. diSessa, and E. Stage (Eds.), Toward a scientific practice of science education (pp. 3 30). Hillsdale, NJ: Lawrence Erlbaum Associates.

[25] Hammer, D. (1996). More than misconceptions: Multiple perspectives on student knowledge and reasoning, and an appropriate role for educational research. American Journal of Physics, 64, 1316 1325. http://dx.doi.org/10.1119/1.18376
[26] Reif, F. (1995). Millikan lecture 1994: Understanding and teaching important scientific thought processes. American Journal of Physics, 63(1), 17 - 32. http://dx.doi.org/10.1119/1.17764

[27] Astin, A. W. (1993). Assessment for excellence: The philosophy and practice of assessment and evaluation in higher education. Phoenix, AZ: American Council on Education and the Oryx Press.

[28] Laws, P. W. (1991). Calculus-based physics without lectures. Physics Today, 44(12), 24 - 31. http://dx.doi.org/10.1063/ 1.881276

[29] Beichner, R. J., Saul, J. M., Allain, R. J., Deardorff, D. L., and Abbott, D. S. (2000). Introduction to SCALE-UP: StudentCentered Activities for Large Enrollment University Physics. Proceedings of the Annual Meeting of the American Society for Engineering Education, Seattle, Washington, Session 2380.

[30] Hake, R. R. (1998). Active-engagement vs. traditional methods: A six thousand student study of mechanics test data for introductory physics courses. American Journal of Physics, 66(1), $64-74$. http://dx.doi.org/10.1119/1.18809

[31] Larkin-Hein, T. (2001). Writing as a teaching and learning tool in SMET education. Journal of SMET Education: Innovations and Research, 2(2/3), $25-35$.

[32] Larkin, T. L. (2009, October), Give it a TWIST!: Turning writing into student thinking.. IEEE/ASEE Frontiers in Education Conference, San Antonio, Texas. Electronic proceedings, Session T4C, pp. 1 - 4. IEEE Catalog Number: CFP09FIE. ISBN: 978-1-42444714-5. Library of Congress: 79-640910. ISSN: 0190-5848.

[33] Larkin, T. L., (2007). Writing: A global Active learning tool in STEM education. International Conference on Engineering and Computer Education (ICECE 2007), Santos/Monguaguá, Brazil, Plenary Session II.

[34] Larkin, T. L. (2011, March). The inclusive classroom: A researchbased approach to enhance learning. Invited paper at the 40th IGIP International Symposium on Engineering Education, São Vicente at the Metropolitan region of Baixada Santista, Brazil.

[35] Larkin, T. L. \& Budny, D. (2008). Peer review from a student perspective. IEEE/ASEE Frontiers in Education Conference, Saratoga Springs, New York. Electronic proceedings, Session F2C, pp. 14 - 15. IEEE Catalog Number: CFP08FIE-CDR. ISBN: 978-14244-1970-8. Library of Congress: 79-640910. ISSN: 0190-5848.

[36] Cummings, K., Marx, J., Thornton, R., and Kuhl, D. (1999). Evaluating innovation in studio physics. Physics Education Research: A Supplement to the American Journal of Physics, 67(7), $\mathrm{S} 38$ - S44.

[37] Thornton, R. and Sokoloff, D. (1990). Learning motion concepts using real time microcomputer-based laboratory tools. American Journal of Physics, 58(9), 858 - 867. http://dx.doi.org/10.1119/ $\underline{1.16350}$

[38] Redish, E. F. and Steinberg, R. N. (1999). Teaching physics: Figuring out what works. Physics Today, 52(1), $24-30$. http://dx.doi.org/10.1063/1.882568

[39] Van Heuvelen, A. (1991). Overview, case study physics. American Journal of Physics, $\underline{59}(10), 898-906$. http://dx.doi.org/10.1119/1.16668

[40] Larkin, T. L. (2013). The evolution of assessment within an introductory physics course. International Journal of Engineering Pedagogy (iJEP), Vol. 3, Special Issue, 1, pp. 39 - 48. Kassel University Press GmbH, Kassel, Germany. eISSN: 2192-4880. http://dx.doi.org/10.3991/ijep.v3is1.2393

[41] Larkin, T. L. (2014, April). The student conference: A model of authentic assessment. International Journal of Engineering Pedagogy (iJEP), Vol. 4, Special Issue, 2, pp. 36 - 46.. Kassel University Press GmbH, Kassel, Germany. eISSN: 2192-4880. http://dx.doi.org/10.39 91 /ijep.v4i2.3445.

\section{AUTHOR}

T. L. Larkin is with American University, Washington, DC USA.

This article is an extended and modified version of a paper presented at the ICL2014 Special Session "Talking about Teaching 2014" (TaT'14), held from 03-ß6 December 2014 in Dubai. Submitted 01 April 2015. Published as resubmitted by the author 07 May 2015. 
PAPER

A RUBRIC TO ENRICH STUDENT WRITING AND UNDERSTANDING

APPENDIX

Conference Paper Formative Assessment Criteria*

\begin{tabular}{|c|c|c|c|c|c|}
\hline & $\begin{array}{c}4 \\
\text { (Outstanding) }\end{array}$ & $\begin{array}{r}3 \\
\text { (Good) }\end{array}$ & $\begin{array}{c}2 \\
\text { (Satisfactory) }\end{array}$ & $\begin{array}{c}1 \\
\text { (Unsatisfactory) }\end{array}$ & $\begin{array}{c}\text { 0 } \\
\text { (Mainly } \\
\text { non-existent) }\end{array}$ \\
\hline Abstract & $\begin{array}{l}\text { The abstract demonstrates } \\
\text { ambition, thoughtfulness, and } \\
\text { appropriate specificity. The } \\
\text { abstract provokes readers to } \\
\text { reflect on the topic's subtleties } \\
\text { and complexities. }\end{array}$ & $\begin{array}{l}\text { The abstract has an } \\
\text { ambitious objective } \\
\text { statement but does not } \\
\text { fully deliver on its } \\
\text { promise. Supporting } \\
\text { arguments progress with } \\
\text { very few lapses in clarity, } \\
\text { soundness, or relevance. }\end{array}$ & $\begin{array}{l}\text { The abstract has an objec- } \\
\text { tive statement, although it } \\
\text { doesn't demonstrate ambition or } \\
\text { take on a discernible degree of } \\
\text { difficulty. The abstract may be } \\
\text { too broad to lead to a focused } \\
\text { paper. }\end{array}$ & $\begin{array}{l}\text { The abstract's unsatisfacto- } \\
\text { ry objective statement suffers } \\
\text { from logical incoherency or facile } \\
\text { aims. Numerous lapses in clarity, } \\
\text { soundness, or relevance. }\end{array}$ & $\begin{array}{l}\text { The abstract has virtu- } \\
\text { ally no discernible objective } \\
\text { or direction. Arguments } \\
\text { often bear no relation to } \\
\text { other sections of the paper; } \\
\text { logical fallacies may } \\
\text { abound. }\end{array}$ \\
\hline Organization & $\begin{array}{l}\quad \text { At the global level he pa- } \\
\text { per's organization develops } \\
\text { organically from an outstanding } \\
\text { abstract. On a local level, the } \\
\text { paper flows with appropriate } \\
\text { transitions between sections and } \\
\text { without unintended interrup- } \\
\text { tions. }\end{array}$ & $\begin{array}{l}\text { At the global level, } \\
\text { the paper's organization } \\
\text { reveals a logical and } \\
\text { effective progression of } \\
\text { the objective as given in } \\
\text { the abstract. On a local } \\
\text { level, transitions between } \\
\text { paragraphs and sentences } \\
\text { create continuity and } \\
\text { coherence. }\end{array}$ & $\begin{array}{l}\text { At the global level, the } \\
\text { paper's organizational strategies } \\
\text { demonstrate basic cohesion and } \\
\text { continuity. On a local level, } \\
\text { transitions between paragraphs } \\
\text { and sentences usually create } \\
\text { continuity and coherence, with } \\
\text { some exceptions. }\end{array}$ & $\begin{array}{l}\text { At the global level, the pa- } \\
\text { per's unsatisfactory organization } \\
\text { results in a paper that confounds } \\
\text { the reader. Locally, paragraphs } \\
\text { stumble from one to the next and } \\
\text { often lack focus and coherence. } \\
\text { Transitions between sections and } \\
\text { sub-sections are largely missing. }\end{array}$ & $\begin{array}{l}\text { At the most basic lev- } \\
\text { el, the paper's paragraphs } \\
\text { lack most defining features } \\
\text { of a traditional paragraph: } \\
\text { controlling ideas, transi- } \\
\text { tions, unity, and coherence. } \\
\text { The same is true of the } \\
\text { paper as a whole. }\end{array}$ \\
\hline $\begin{array}{l}\text { Introduction/ } \\
\text { Historical } \\
\text { Overview }\end{array}$ & $\begin{array}{l}\text { Provides a thorough and } \\
\text { very clear historical context to } \\
\text { the paper. }\end{array}$ & $\begin{array}{l}\text { Provides a reasona- } \\
\text { bly thorough and clear } \\
\text { historical context to the } \\
\text { paper. }\end{array}$ & $\begin{array}{l}\text { Provides a modest and } \\
\text { mostly clear historical context } \\
\text { to the paper. }\end{array}$ & $\begin{array}{l}\text { Provides a minimal and } \\
\text { mostly unclear historical context } \\
\text { to the paper. }\end{array}$ & $\begin{array}{l}\text { Provides little or no } \\
\text { historical context to the } \\
\text { paper. }\end{array}$ \\
\hline $\begin{array}{l}\text { Physics Syn- } \\
\text { thesis }\end{array}$ & $\begin{array}{l}\quad \text { Provides an excellent } \\
\text { overview of key physics } \\
\text { concepts at a level appropriate } \\
\text { for the target audience. }\end{array}$ & $\begin{array}{l}\quad \text { Provides a strong } \\
\text { overview of key physics } \\
\text { concepts at a level } \\
\text { appropriate for the target } \\
\text { audience. }\end{array}$ & $\begin{array}{l}\text { Provides a modest over- } \\
\text { view of key physics concepts at } \\
\text { a level appropriate for the target } \\
\text { audience. }\end{array}$ & $\begin{array}{l}\quad \text { Provides weak or minimal } \\
\text { overview of key physics concepts } \\
\text { at a level appropriate for the } \\
\text { target audience. }\end{array}$ & $\begin{array}{l}\quad \text { Provides little or no } \\
\text { overview of key physics } \\
\text { concepts at a level appropri- } \\
\text { ate for the target audience. }\end{array}$ \\
\hline $\begin{array}{l}\text { Connection } \\
\text { between Key } \\
\text { Physics Con- } \\
\text { cepts and } \\
\text { Paper Topic }\end{array}$ & $\begin{array}{l}\text { Connections made are } \\
\text { clearly outstanding and demon- } \\
\text { strate a clear and strong } \\
\text { understanding of the topic. }\end{array}$ & $\begin{array}{l}\quad \text { Connections made } \\
\text { are strong, and demon- } \\
\text { strate a good understand- } \\
\text { ing of the topic. }\end{array}$ & $\begin{array}{l}\text { Connections made } \\
\text { demonstrate a basic understand- } \\
\text { ing of the topic. }\end{array}$ & $\begin{array}{l}\text { Connections made demon- } \\
\text { strate a weak understanding of } \\
\text { the topic. }\end{array}$ & $\begin{array}{l}\text { Connections made are } \\
\text { largely absent reflecting } \\
\text { little or no understanding of } \\
\text { the topic. }\end{array}$ \\
\hline Summary & $\begin{array}{l}\text { Provides an excellent syn- } \\
\text { thesis of key ideas. }\end{array}$ & $\begin{array}{l}\text { Provides a strong } \\
\text { synthesis of key ideas. }\end{array}$ & $\begin{array}{l}\text { Provides a modest synthe- } \\
\text { sis of key ideas. }\end{array}$ & $\begin{array}{l}\text { Provides a weak synthesis } \\
\text { of key ideas. }\end{array}$ & $\begin{array}{l}\text { Provides little or no } \\
\text { synthesis of key ideas. }\end{array}$ \\
\hline Correctness & $\begin{array}{l}\text { The writing has virtually } \\
\text { no grammatical, mechanical, or } \\
\text { formatting errors. Sources are } \\
\text { appropriately attributed, } \\
\text { documented, and cited. At this } \\
\text { level, the presentation reveals } \\
\text { professionalism and attention to } \\
\text { detail. }\end{array}$ & $\begin{array}{l}\text { The writing has few } \\
\text { grammatical, mechanical, } \\
\text { or formatting errors, and } \\
\text { they do not distract the } \\
\text { reader from the content. } \\
\text { Sources are appropriately } \\
\text { attributed and cited with } \\
\text { very few errors. }\end{array}$ & $\begin{array}{l}\text { The writing has several } \\
\text { grammatical, mechanical, or } \\
\text { formatting errors, and some } \\
\text { errors distract the reader from } \\
\text { the content. Sources are } \\
\text { documented and cited, though } \\
\text { not always strictly in an } \\
\text { appropriate format. }\end{array}$ & $\begin{array}{l}\text { The writing has substantial } \\
\text { grammatical, mechanical, or } \\
\text { formatting errors that distract the } \\
\text { reader from the content. Many } \\
\text { sources are incorrectly docu- } \\
\text { mented and cited. }\end{array}$ & $\begin{array}{l}\text { The paper fails to meet } \\
\text { minimum standards of } \\
\text { correctness: errors in } \\
\text { grammar or mechanics } \\
\text { prevent readers from } \\
\text { understanding the paper. } \\
\text { Sources receive incorrect or } \\
\text { no documentation and } \\
\text { citation. }\end{array}$ \\
\hline $\begin{array}{l}\text { Reference } \\
\text { Section and } \\
\text { Citations }\end{array}$ & $\begin{array}{l}\text { All cited works are done in } \\
\text { the correct format with no } \\
\text { errors. At least } 50 \% \text { are from } \\
\text { non-web sources. }\end{array}$ & $\begin{array}{l}\quad \text { Some cited works } \\
\text { are in the correct format. } \\
\text { Maintains mostly a good } \\
\text { balance between web- and } \\
\text { non-web sources. }\end{array}$ & $\begin{array}{l}\text { Few cited works. Done on } \\
\text { the correct format with some } \\
\text { errors. Over-emphasis on web } \\
\text { sources and insufficient major } \\
\text { references. }\end{array}$ & $\begin{array}{l}\text { Few cited works. Done in } \\
\text { the correct format with many } \\
\text { errors. }\end{array}$ & $\begin{array}{c}\text { Absent or the only } \\
\text { sources cited are web-based. }\end{array}$ \\
\hline
\end{tabular}

*Adapted from AU's College Writing Program Grading Criteria.

Author:

Number of fully formatted pages submitted (5-page minimum): 